PUNISHING THE MENTALLY ILL:

HUMAN RIGHTS CONCERNS IN

CANADIAN IMMIGRATION DETENTION POLICY \& PRACTICE

by

Laroux Peoples, BA, University of Toronto, 2004

A Major Research Paper

presented to Ryerson University

in partial fulfillment of the requirements for the degree of

Master of Arts

in the Program of

Immigration and Settlement Studies

Toronto, Ontario, Canada, 2007

(C) Laroux Peoples 2007 
UMI Number: EC53437

\section{INFORMATION TO USERS}

The quality of this reproduction is dependent upon the quality of the copy submitted. Broken or indistinct print, colored or poor quality illustrations and photographs, print bleed-through, substandard margins, and improper alignment can adversely affect reproduction.

In the unlikely event that the author did not send a complete manuscript and there are missing pages, these will be noted. Also, if unauthorized copyright material had to be removed, a note will indicate the deletion.

\section{UMI}

UMI Microform EC53437

Copyright 2009 by ProQuest LLC

All rights reserved. This microform edition is protected against unauthorized copying under Title 17, United States Code.

ProQuest LLC

789 East Eisenhower Parkway

P.O. Box 1346

Ann Arbor, MI 48106-1346 
I hereby declare that I am the sole author of this major research paper.

I authorize Ryerson University to lend this paper to other institutions or individuals for the purpose of scholarly research.

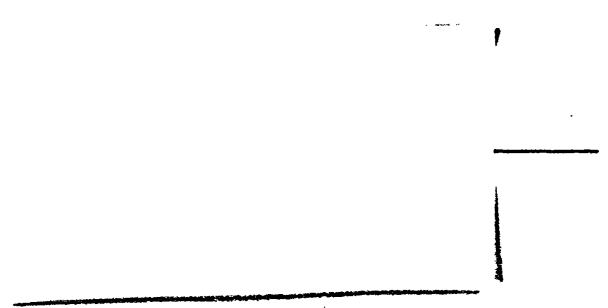

I further authorize Ryerson University to reproduce this paper by photocopying or by other means, in total or in part, at the request of other institutions or individuals for the purpose of scholarly research.

$\overline{\mathrm{S}}$

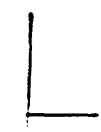




\title{
PUNISHING THE MENTALLY ILL: \\ HUMAN RIGHTS CONCERNS IN \\ CANADIAN IMMIGRATION DETENTION POLICY \& PRACTICE
}

CC Laroux Peoples, 2007

\author{
Master of Arts \\ Immigration and Settlement Studies \\ Ryerson University
}

\begin{abstract}
Canadian prisons house persons who have never committed a crime but who have immigration problems and a mental illness. This paper explores why this is happening by reviewing current immigration legislation, past policy shifts, public opinion about immigrants and persons with a mental illness, and the role of political elites and the media in shaping the issues.
\end{abstract}

Key Words:

immigration policy; mental illness; immigration detention. 


\section{Introduction}

The treatment of immigration detainees with mental health issues is not a subject that often comes up when discussing immigration policy. It thus appears unimportant, when compared to the discussion of how many people to admit, what selection criteria is used and so forth. Yet the topic touches on two of the most fundamental parts of the immigration process; the issue of immigrant selection - who to select and why and, immigrant settlement - what rights and entitlements immigrants have once they are living in Canada. Part of the reason for the lack of attention relates to misperceptions about individuals with a mental illness.

Government legislators, the medical community and public perceptions of persons with a mental illness have been largely negative. Persons labeled as 'mentally ill' are typically thought to be dangerous, untrustworthy or incapable of directing their own life. This has resulted in increased stigma and discrimination that persons with a mental illness feel in all areas of social life. ${ }^{1}$

The immigration status of a person further complicates the issue. The Canadian public and government policy-makers often stigmatize persons not born in Canada, resulting in discrimination when immigrants seek jobs, rent or buy property or bring modes of cultural behavior not deemed appropriate by the dominant culture. ${ }^{2}$

The immigrant experience is hardly monolithic and is complicated by race, class and gender, forming new combinations of stigma and discrimination, and making each persons' challenges unique. The intersections between immigration and gender, class, and race have been the subject of some academic attention in recent years. ${ }^{3}$ 
The subject of this paper is an area where little academic research exists. Virtually no one in Canada has studied how mental health status intersects with the immigrant experience resulting in new forms of discrimination in the context of immigration detention. Before embarking on an analysis of immigration and detention in relation to mental health, it is important to discuss what we mean by mental health versus mental illness.

Mental health refers to the capacity to "think, feel and act in ways that enhance our ability to enjoy life and deal with the challenges we face" (Health Canada: 2006: 2). Mental illness refers to any symptoms or diagnosis related to distress that prevents a person from functioning. Illnesses range from mild to severe.

It is unfair to give a group the label 'the mentally ill'. Persons who deal with mental illness have a range of experiences and live in a variety of conditions.

Generalizations can reinforce stereotypes, leading to further stigmatization which inhibits the development of more appropriate mental health policy. This label has already resulted in poor policy outcomes, particularly in the context of immigration detention. This paper will show that those labeled as 'mentally ill' often receive punitive treatment as a result being categorized as dangerous. Despite this, this paper will use the term 'the mentally ill', understanding that while it is a problematic category, that using it will help to discover the ways in which persons affected by the label are being treated. The next section focuses on the main research questions to be addressed in this paper.

\section{Research Questions}

The central and overarching research question to be explored is why the human rights of persons with a mental illness are being violated in the context of immigration 
detention. What enables this process and how has the transition to neoliberal modes of governance in Canada impacted the ways in which mentally ill immigration detainees are treated? The specific focus is on migrants caught in the immigration detention system, although attention will be paid to issues facing both detained and non-detained immigrants alike. Addressing this issue involves contemplating two questions, one historical and the other sociological. The historical question focuses on how change occurred and why that change occurred in the manner it did. The sociological question examines these changes in light of the social, economic and cultural shifts that have occurred in Canada.

\section{Overview}

This paper will trace the shifts that have occurred over the past few decades in legislation and policy in relation to mental health detainees.

The first main section provides a glimpse of the current context, both in terms of immigration detention legislation, guiding practices and the treatment of detainees. An example from Australia regarding mental health services in immigration detention will also be explored in the context of serving as a chilling reminder of the need for reforms in Canada.

What follows is an historical analysis, using the rise of neoliberalism as a context to understand the treatment of mentally ill immigrants and to explore the shifts that occurred following the rise of neoliberalism in the 1980s and new permutations developing in the time prior to, and immediately following, the attacks of September $11^{\text {th }}$. 
While the particular focus in on immigrants with mental health issues, attention will be paid to the treatment of refugee claimants more broadly.

The next section locates this topic within a theoretical framework, whereby the language and apparatus of crime and criminal justice have infiltrated the immigration and detention system. For example, the increasing use of risk management techniques for controlling persons with a mental illness will be explored in relation to the immigration system.

The final section will attempt to bring together the main arguments and offer some policy suggestions and future possibilities for research in this area.

\section{The Present Context}

In order to explore the treatment of mentally ill detainees it is necessary to examine the most current Canadian immigration legislation and guidelines. To show how the situation compares, a recent example of an immigration detainee from Australia who was terribly mistreated while in detention will be examined to show what can happen if guidelines and measures for the mentally ill are not put in place. Much can be learned from the Australian context where the issue of the rights of mentally ill detainees has become a priority. This section will largely examine the issue of refugee claimants, the impact of detention on those with a mental illness, and the practice in place of using punitive measures to control the mentally ill. 


\section{IRPA and Immigration Detention}

Drafted in February of 2001, Canada's current immigration legislation is the Immigration and Refugee Protection Act (IRPA). Under the Act, a person without citizenship (known as a 'foreign national') can be detained for three reasons: if there are reasonable grounds to believe they will not appear for immigration proceedings, if they are a danger to the public, or if they are uncooperative in establishing their identity and/or their identity is unknown (IRPA 2002 Section 58 (1)).

The detention of immigrants without secure immigration status is not a new phenomenon. In the interwar years, the Canadian government routinely detained and deported foreign-born labour activists in order, to contain the perceived threat of Communism. ${ }^{4}$ The detention policies of today mark a departure from the past in two ways: refugee claimants have been redefined as a threat to Canadian security and subject to increased detention, and the supposedly administrative holding sites for immigration detainees have become more criminal justice oriented and a more permanent feature of the immigration system (Pratt: 2005).

The identity provision of IRPA, first introduced in the mid 1980s, punishes refugee claimants who use smugglers to arrive in Canada and false documents to exit their country of origin (Amnesty International Canada "Response to the Report of the Legislative Advisory Group": 1988). When international refugee flows became more pronounced in the 1980s, Canada imposed visa requirements on visitors from many refugee-producing states (Adelman 1991: 208). All refugee claimants arriving without proper identity documents can be detained until either they satisfy their identity 
requirements or convince the government that they have cooperated and made their best efforts to obtain documents (CIC Immigration Manual ENF 20 Section 5.8).

The result is that refugee claimants held on identity grounds must often wait in detention facilities until their documents arrive, a process that can take anywhere from three to eight months. This can result in lengthy detention in immigration facilities, forcing the detainee to prepare their refugee hearing while in detention and living with the uncertainty of when they will be released (Pratt 2005: 48).

Long term detention can have an impact on persons who have experienced trauma, in particular refugee claimants. Refugee claimants are particularly vulnerable to poor mental health status upon arrival to Canada due to the often traumatic situations that led them to flee their country of origin (Beiser 2005: S30). A 1988 Canadian study on the mental health of immigrants and refugees found that refugees living in Canada do not access mental health services, often out of fear of danger or social stigma. "They are in double jeopardy - their risk for developing disorder is high and the chances of their needs being addressed is low" (Mental Health Task Force Report 1988: 63). Studies in Australia and the UK have linked a decline in mental health to the detention of refugee claimant. This is attributed to the unknown duration of their stay in detention, and to the reality of being detained after having escaped a traumatic situation. Symptoms can range from Post Traumatic Stress Disorder to suicide attempts (Pourgourides 1998: 204). ${ }^{5}$

The government rationale for detaining for identity reasons centers around the lack of cooperation on the part of the detainee and issues of security (i.e., not knowing who is entering Canada). ${ }^{6}$ In 1997, the House of Commons Standing Committee on Citizenship and Immigration published research findings on major aspects of immigration 
legislation, including detention provisions. There are no mandatory detention policies in Canada, and the Committee reviewed whether or not immigration detention is necessary, and, if so, for whom it should be used. They found that individuals arriving without documents who do not cooperate with officials should be detained and that detention is a necessary measure of immigration control, thus placing the rational for detention due to an individuals 'decision' to be uncooperative (Legislative Advisory Group: Not Just Numbers: A Canadian Framework for Future Immigration Executive Summary 1997: 8). Amnesty International, in response to the Committee's report, argued that refugee claimants are given an unfair barometer to measure their cooperation, increasing their chances of detention. Often, refugee claimants have no choice but to be 'uncooperative' as defined by the legislation - in order to protect their safety (Amnesty International Canada: Response to the Report of the Legislative Advisory Group: 1988: 20). An undocumented person arriving at the airport to claim refugee status is often immediately asked to sign documents requesting permission to be issued a passport from their embassy. This is a measure immigration officers use to determine if a refugee claimant is being cooperative and whether or not to detain them. The problem is that refugee claimants may have valid fears for signing passport authorization documents and may wish to be cooperative, but cannot sign a passport documents for fear of their own safety. In signing, their home country (from which they are claiming asylum) will learn that they have left the country, have not complied with exit requirements, and that they are a refugee claimant. Defining 'cooperation' in such a way, is unfairly punitive and places unnecessary and excessive stress on persons who are already facing trauma (Amnesty 
International Canada: Response to the Report of the Legislative Advisory Group: 1988: 19).

One could argue that refugee claimants who arrive without identity documents and with a mental illness other than Post Traumatic Stress Syndrome would have a greater risk of being detained, particularly if their illness is not identified by the investigating officer. If detention can exacerbate the symptoms of a mental illness, and it goes undetected, the detainees' refusal to help authorities to recover identity documents would be classified as 'uncooperative'. Legislation that makes detention appear to be the result of an individual's actions, such as the case of the identity threshold, unfairly punishes inland refugee claimants and places those with a mental illness at further risk to long term detention. The environment of the detention centre in Toronto (Canada's largest immigration holding site) is punitive, similar to prison life, and is no place for a person with a mental illness.

\section{Experiencing Immigration Detention}

Most detainees arrive at a facility in restraints such as handcuffs, leg irons or shackles. They are put in a holding room where their shoes are taken off and examined and they are searched by a guard of the same sex. Any belongings are searched and tagged. A detainee is allowed to bring clothes and some money to their room but the rest of their belongings are locked away in a separate room. Once inside their room, a detainee must remain there. Exceptions include certain activities that operate according to a schedule such as meals, using the telephone, outdoor activities or if a lawyer or the onsite medical doctor or nurse requests to see them (Pratt 2005: 37, 39 - 40). 
Detainees are always in the presence of an escort if outside their room and their movements are recorded by security guards. Guards also perform surprise room checks and searches as well as indoor and outdoor patrols. If a person tries to escape, security guards are allowed to use "necessary force" to contain them. (Pratt 2005: 40).

No mental health facilities exist in detention facilities. An on-site doctor is present and has the ability to refer a patient to outside mental health care though this rarely happens in practice For instance, persons who attempt suicide are more likely to be transferred to provincial jails - the government rational for this being that jails are better equipped to monitor detainees (Pratt 2005: 41). The transfer of a person in mental distress to a prison facility does not seem to be the appropriate solution.

The experience of living in a detention centre for all detainees, regardless of the status of their mental health, involves being monitored, having their movements restricted and having limited access to the outside world. Immigration violations are administrative and not criminal in legal terms, yet persons in immigration detention are being treated like criminals. Anna Pratt argues that immigration enforcement practices have in fact moved closer to the criminal justice sphere, particularly in the way that detained immigrants are perceived as risks and how they are managed (Pratt 2005: 37, 39). The ways in which this impacts persons with a mental illness caught in the immigration detention system places them at greater risk to their well-being, particularly when these individuals have not committed a criminal offence.

Prisons are not a suitable environment for persons with a mental illness. Jamie Fellner argues this is because the prison system is about security, power and control. Obeying prison rules is the most significant aspect of prison life and mentally ill inmates. 
Those who may already have an unusually hard time following rules thus receive unnecessary punishment while in prison. Fellner asserts this claim using US data showing that mentally ill inmates are more likely to be punished by jail workers than the rest of the prison population (Fellner 2006: 395-6). If Canadian immigration complexes resemble jails, they are clearly not a good environment for the mentally ill.

\section{Legislative Protections for the Mentally III}

While there exist some legislative guidelines regarding persons with mental health issues, the guidelines cover few aspects of a detainees' day-to-day life and their interaction with security guards. According to operating manuals for immigration officers, detention should be used as a last resort as persons with a mental illness are considered a 'vulnerable' population. The manual indicates that alternatives to detention ought to be considered whenever possible (CIC Immigration Manual ENF 20 Section 5.13: 15-16). Immigration officers are not psychiatrists and are likely unable to evaluate a detainees' mental health accurately. In addition, immigration legislation emphasizes risk management and the threat unidentified foreign nationals present to Canadians.

Discretionary regulations enable officers to detain persons with a mental illness. Taken together, a system is created where immigration officers engaging in risk management are compelled to choose detention. An analysis of how persons with a mental illness came to be viewed by immigration policy makers as risky and threatening, along with the ramifications of this shift will be explored in later sections.

Policy guidelines with respect to the mentally ill also exist for detention reviews. These reviews are the administrative hearing accorded each detainee to determine 
whether or not they are suitable for release. The Immigration Division, the body responsible for detention reviews, defines persons with a mental illness as vulnerable and states that, "like all persons appearing before the IRB, vulnerable persons need to be treated with sensitivity and respect, but they also need to have their cases processed taking into account their specific vulnerabilities" (IRB - Guidelines on Procedures with Respect to Vulnerable Persons Section $1-1.5)$. Unfortunately these guidelines only deal with the procedural component of detention reviews. The most vital parts affecting a person with a mental illness in detention are whether to release the detainee given their medical circumstances and consideration of the impact of the punitive environment on their mental health. Neither of these issues fall under the IRB guidelines on vulnerable groups meaning that the protections given to not protect the mentally ill in situations where it is needed the most.

In fact, there are guidelines in an enforcement manual on detention that reinforce the stigma and stereotyping of persons with a mental illness and make detention more likely and release more difficult. As mentioned earlier, a person can be held in immigration detention if they are found to be a danger to the public. The manual sets out several criteria immigration officers must use when determining whether a person is a danger to the public. Included in these is a section on 'mental imbalance'. A person showing signs of 'mentally unstable behavior' during an initial examination can be classified as a danger to the public as this type of behavior "may be a very important indicator in the assessment of the danger, and may point to future violent behavior" (CIC Immigration Manual ENF 20 Detention Manual Section 5.6: 6). 
The problem with this is the unfair association of mental illness with violent and threatening behavior, a stereotype which has little scientific basis given that persons with a mental illness are much more likely to harm themselves and not others (Senate Standing Committee on Social Affairs, Science and Technology: "Mental Health, Mental Illness and Addiction Report 1": 45). So long as a person is considered a danger to the public, they are unable to be released from immigration detention, leading to long term detention. Unlike the criminal justice system, the detainee is not given a specific release date. This provision shares something in common with the IRB's guidelines on vulnerable groups - it creates a more punitive environment for persons with a mental illness. This is a problem and one in which the government of Australia has dealt with recently.

\section{Australia vs. Canada - The Case of Cornelia Rau}

The governing of all detainees is contracted out to private security firms in Canada. This means that private companies employ security guards who have the most direct contact with detainees, and are the persons responsible for discipline and regulation of behavior inside the detention sites (Pratt 2005: 36). Australia also contracts out detention work to private security companies. The Department of Immigration \& Multicultural \& Indigenous Affairs (DIMIA) has come under fire for its mistreatment and neglect of detainees with mental health issues, in part due to their mismanagement as a result of governing from a distance - where the day-to-day handling of prisoners and immigration detainees is no longer the responsibility of government officials but private security companies (Pratt 2005: 34, 36). Several public inquiries and lawsuits regarding 
the mistreatment of mentally ill immigration detainees have sparked public outrage resulting in changes in the administration of mental health treatment in detention centres. ${ }^{7}$

It is possible to compare Australia and Canada's immigration detention systems even though on the surface, both countries seem to have different systems. Australia instituted a mandatory detention policy for refugee claimants (including children) arriving without identity documents in 1994, as a response to large numbers of persons arriving by boat to claim refugee status in the late 1980s. There are significantly larger numbers of persons landing in Australia to make refugee claims than in Canada. The number of detainees held nation wide in Australia recorded during a visit by the UN Working Group on Detention in May of 2002 was 1,500 (UN Working Group on Arbitrary Detention Visit to Canada Report: 6). During that same year, Citizenship and Immigration Canada released a report of detention statistics, stating that on any given day in 2002, roughly 440 were being held in Canada for immigration reasons, roughly a third of the number of immigration detainees in Australia.

No immigration department in the West wants to be compared to Australia which has the most widely criticized detention policies. When Greg Fyffe, then deputy minister for Citizenship and Immigration, was asked at an evidence session in 1998 for the Standing Committee on Citizenship and Immigration how current Canadian detention practices for refugee claimants compare to the Australian context, he argued that Australia faces different problems and has a unique system, one where Australians are comfortable with mandatory detention. According to Fyffe, the Canadian system cannot be compared (Standing Committee on Citizenship and Immigration Evidence session April 22, 1998). 
Yet detention centres in Canada can be compared to their Australian counterparts in one very important way - both are run by private security firms which impacts how mentally ill detainees are treated and their access to mental health supports.

As demonstrated, contemporary Canadian legislation and detention guidelines provide few meaningful legislative protections for mentally ill detainees in terms of either their treatment while in a detention facility or their access to mental health supports. An Australian example, the case of Cornelia Rau, shows how mismanagement turns into mistreatment resulting in human rights violations.

Cornelia Rau, a German citizen with chronic schizophrenia who had lived in Australia for many years, found herself in Australian immigration detention for ten months. Ms. Rau's story has sparked public outrage at the mistreatment of detainees, particularly those with a mental illness, and is part of a number of key events that have resulted in policy change in this area. Her story highlights the problem of outsourcing immigration detention and the lack of legislative guidelines requiring mental health sensitivity training for detention centre staff - two problems plaguing the Canadian system. What follows is information drawn from a public inquiry into her case known as the Palmer report as well as from an article by Lynda Crowley-Cyr.

Cornelia Rau was receiving psychiatric treatment at a facility when she wandered off the hospital property. She hitchhiked and as a result of a public disturbance incident, was picked up by police in March of 2004. Ms. Rau was detained for immigration reasons because she could not provide police with proper identification and gave the police conflicting accounts of her life history, her name, and her birthplace. While her parents had filed a missing persons report with local police authorities, immigration 
authorities neglected to follow up with any missing persons' bureau (Palmer 2005: 12). By this time, Ms. Rau was off her medication, and immigration authorities placed her in a women's prison for the first six months of her immigration detention, despite the fact that she had committed no criminal acts (Palmer 2005: 14).

Attempts were made to deport Ms. Rau to Germany, despite the fact that all her family was looking for her in Australia. The symptoms of her illness were unrecognizable to immigration enforcement staff. Ms. Rau was not classified her as a person with a mental illness, and so punitive measures were used to control her behavior. Immigration officials, according to an inquiry, also repeatedly ignored the pleas from fellow immigration detainees that Ms. Rau receive a psychiatric assessment. When placing her in isolation along with other punitive measures seemed to make things worse, Ms. Rau was eventually given access to mental health supports (Crowley-Cyr 2005: para 65).

Ms. Rau was transferred to Baxter, an immigration detention site that prior to and during the inquiry, was found to be a poorly managed facility with little access to proper mental health care. At Baxter, she was seen by in-house medical personnel who misdiagnosed her erratic behavior (frequent crying, violent episodes and pacing) as attention-seeking. Following the diagnosis of the medical staff, enforcement officials decided to use punitive measures to control her behavior, placing her in an isolation wing. Needless to say, her condition greatly deteriorated (Crowley-Cyr 2005: para 67).

Some time passed and eventually medical personnel concerned with Ms. Rau's condition requested off-site mental health assistance and booked an appointment with an off-site psychiatrist for her. There was an unusual delay given the remote location of Baxter. Once an off-site psychiatrist came to Baxter, he concluded that Ms. Rau likely 
had schizophrenia. He requested that the guards not place her in isolation given that isolation can exacerbate symptoms for schizophrenic persons. Immigration personnel ignored these requests and detainees recounted that it often took three to four immigration personnel to get her into a solitary cell each night (Crowley-Cyr 2005: 70).

Finally, non-governmental organizations were alerted to Ms. Rau's case and after an aggressive media campaign, Ms. Rau's family identified her from a newspaper story and she was released from immigration detention and transferred directly to a mental health hospital (Crowley-Cyr 2005: 71).

Some of the problems the Palmer report identified were the lack of mental health sensitivity training afforded detention personnel, the lack of coordination between the detention facility and DIMIA and the lack of management initiative and case management on the part of DIMIA that resulted from outsourcing. Policy recommendations included external assessment of caseload management, the development of a more rigorous mental health case management support system inside detention facilities, and rigorous training on policies and procedures for detention centre staff (Palmer 2005: x-xiii).

The government of Australia did adopt some of the policy changes specific to the concerns regarding the Baxter facility and its policies for persons seeking mental health supports. These include a new health delivery model based on client-driven needs, more frequent visits by off-site mental health physicians, regular internal audits to ensure programs run more smoothly, and new training of detention centre employees on policies and procedures and mental health sensitivity. Also in 2005, Prime Minister John Howard delivered a public apology to Ms. Rau and promised a compensation package. 
It took a crisis in public confidence, for new policy directions aimed at protecting the interests of detained persons with a mental illness to be created. The challenge for Canadian policy-makers is to make more explicit protections for vulnerable groups like the mentally ill to prevent a situation like Ms. Rau's from happening in Canada.

The next section reviews some major sociological and legislative changes in Canada that led to the present detention system and treatment of the mentally ill.

\section{The Historical Context}

In trying to determine how broader political and social shifts have influenced the present detention of mentally ill non-status persons in Canadian jails; it is important to discuss neoliberalism, as both an ideology and a mode of governing. Three periods will be examined that spotlight the forms of governance and discourse associated with immigrants and mental health.

\section{Immigration Health Policy in the Pre-Neoliberal Era}

In the $17^{\text {th }}$ and early $18^{\text {th }}$ century, mental illness was thought of in Europe and North America as a physical condition brought upon by the presence of too much passion. Common methods of treatment were confinement in cages and the use of restraints. By the late $18^{\text {th }}$ century, a more humane approach to the treatment of the mentally ill emerged. Philippe Pinel, a French doctor and William Tuke, an Englishman, removed restraints from mentally ill patients, interacted with them as they would anyone else, with respect and care, and provided facilities that were non-punitive. This came to 
be known as the "moral treatment" approach and it spread across Europe and into Canada.

By 1900, mental health facilities (asylums) emerged across Canada and other Western countries as a result of the widespread belief in the "moral treatment" approach. Prior to the advent of asylums, the mentally ill were held in prisons, at family homes or in the care of their church (Senate Standing Committee on Social Affairs, Science and Technology: "Mental Health, Mental Illness and Addiction Report 1": 134-6).

In the late 1870s, recent immigrants to Canada were placed in asylums and received treatment alongside Canadian-born patients. This greatly annoyed Charles Kirk Clark, a man who would become Canada's first well known psychiatrist and political lobbiest for mental health research. Clark felt that Canada was a dumping ground for the poor, the mentally and physically diseased and morally corrupt citizens of the world (Beiser 2005: S32). To him, immigrant patients in mental health facilities got in the way of research. They also hindered his ultimate goal - to prove to the Canadian public that mental illness could be cured. He reached these conclusions due to his experience with immigrant patients. Immigrants arriving in the urban centres of Canada, were often transferred to asylums outside of Toronto, particularly the Kingston asylum were he worked (Dowbiggin 1995: 609).

As such, Clark began lobbying the Canadian government to amend its immigration legislation. He had some success. In 1906, the Immigration Act was amended and any immigrant found to be hospitalized due to a mental illness, within two years of arrival to Canada, would be subject to deportation for being a public charge 
(Kelley and Trebilcock 1998: 136). From 1900-1940, 1,000 immigrants were deported under the category of 'feeble-mindedness' (Beiser 2005: S32).

Very little discussion as to the rights and entitlements of immigrants to health care services was discussed. Clark's opinion was that the state owed nothing to an immigrant who developed a mental illness no matter how long they had been living in Canada. He likened them to criminals, a harbinger of things to come, making it seem as if asking for mental health services was a crime that should be punished with deportation (Dowbiggin 1995: 608). This pre-dates the era associated with neoliberal governance and yet Clark's ideas and the government response indicate an early predisposition towards prioritizing self-reliance in immigrant settlement. It also shows the ideology of rights and entitlement of Canadian born persons being above those of immigrants - particularly in accessing mental health supports.

The development and implementation of broad-ranging federally funded social programs in health, education, income assistance emerged from the 1950 s to the 1970 s in a period of governance known as welfare liberalism which affected Canada, the United States, Australia and other Western nations. Welfare liberalism is a form of governance ensuring that anyone, who through no fault of their own, is unable to work due to illness, unemployment, or disability receives a minimum level of income assistance (Nicholas Rose: 1999). This is known as the 'golden era' of government where many areas of social programming including health, welfare and education were expanded due to the primacy given Keynesian economics (Seddon 2007: 150).

In the 1980s and 1990s, government policy-makers shifted away from welfare liberalism and developed changes in the areas of welfare and immigration that would 
affect migrants with a mental illness. A discussion of neoliberalism reveals the substance of these new changes.

\section{Neoliberalism and its impact on immigration policy}

As an ideology, neoliberalism suggests that the state needs to pull back from its involvement in the economy since lending too much assistance can slow economic and social development (Clark 2002: 771). Yet neoliberalism is also a 'way of governing' (Pratt \& Valverde 2002: 139). This mode of governing grew popular in the Canadian political system in the 1980s, driven in large part by the MacDonald Royal Commission on the Economic Union and Development Prospects for Canada. Policy reforms for multiple areas were decided upon in the commission and carried through by federal bureaucrats and political parties (Clark 2002: 775).

The neoliberal logic was applied to immigration and settlement policy in various ways. On the one hand, state sponsored social assistance, including medical benefits, were cut during the 1990s (Steele et. al 2002: 119). On the other, the state increased its exercise of power by developing enforcement oriented immigration detention facilities and by establishment of an agency charged with using law and order as a means to control border entry, the Canada Border Services Agency (CBSA) (Pratt: 2005).

If too much state involvement was seen as bad for the economy, the government saw fit to privatize many services in multiple areas of public policy, including the corrections system and the immigration detention system. The result is the principle of governing from a distance. The question of government accountability, particularly for the treatment of mentally ill detainees, is of concern in the neoliberal era. 
Neoliberal outsourcing has also complicated the provision of mental health services for immigration detainees. The Interim Federal Health Program provides health care coverage in Canada for refugee claimants and all persons in immigration detention centres who are unable to pay for medical services. The program was transferred from Health Canada to Citizenship and Immigration Canada in 1995, coinciding with the development of neoliberal policies in other areas of immigration and health policy. Those enrolled in the program receive less extensive health care coverage than permanent residents. It covers only essential and emergency services. For mental health services such as psychiatrists, psychotherapy and counseling, prior approval from CIC headquarters in Ottawa is needed (Gagnon 2002: 11).

The plan is now administered by a private company - Funds Administrative Service Incorporated. Dr. Sylvie Martin, a representative for the Immigration Health Program Elaboration at CIC has said that "Citizenship and Immigration Canada is not a department that plays a major role in the delivery of mental health services (emphasis added)" (The Standing Senate Committee on Social Affairs, Science and Technology Evidence Session: February 23, 2005). It is no wonder that mental health service provision is the exception in the provision of health services. The number of steps required for someone to access mental health supports in a detained setting are extensive and act as a barrier for mental health specialists seeking to assist patients. A person in detention requiring mental health support requires a referral from a physician, approval from Ottawa CIC headquarters to cover the cost and coordination with the Funds Administrative Service for payment (Gagnon 2002: 12). 
The Interim Federal Health program also reduced coverage as previously mentioned to 'essential' and 'emergency' services. Such cuts to social services (including health care) were part of a broader 'moral campaign' waged against persons in Canada using social assistance. The main argument is that cutting social assistance can reduce the burden of tax-payers, help foster a healthy work ethic among persons on welfare, and prevent the development of welfare dependency. Self-reliance is a cornerstone of neoliberalism (Pratt \& Valverde 2002: 139; Arat-Koc 1999: 34).

Shifting the composition of immigrants arriving in Canada is another way that the government has emphasized self-reliance. Since the mid 1970s there have been, roughly speaking, three major immigration classes that are admitted to Canada - refugees, family class, and independent/economic immigrants (Kelley and Trebilcock 1998: 347). In the mid 1980s, the government began steadily increasing persons in the independent class category and decreasing the number of 'humanitarian' admissions - refugees and family class immigrants. Refugees, unlike economic immigrants, do not have to show that they can get by financially during the initial settlement period. While persons sponsoring family often have to show that they can support them financially, they are often children or parents of immigrants - persons not capable of entering the workforce. Throughout the 1980s, persons in the economic class made up one-third to one-half of all immigrants entering Canada. By the mid-nineties, they made up over half of all immigrants admitted (Li 2003: 81).

In 1986, the government expanded the economic class by introducing the investor program. This enabled would-be migrants to side-step the traditional criteria and wait times for entry. The major criteria for admission was finances and a provable history of 
working in the business sector. From 1981 to 1990 - this sub-set of the economic class grew much more quickly than all the other classes, including the regular economic class (Knowles 1997: 188).

The preference for selection of these classes was clear - they would not drain the social assistance system. It must be stressed that this period in immigration policy explicitly questioned the value of the welfare state and became increasingly hostile to the needs of resettled immigrants and refugees. Any migrant requiring mental health services was stigmatized. The next section focuses on specific ways that neoliberal governance affected immigrants with a mental illness.

\section{Neoliberal governance in the 1980s and 1990s}

Refugee claimants, welfare assistance, immigration detention and mental health services are often considered isolated policy areas yet throughout the 1980s and 1990s, several initiatives had the effect of combining these areas for persons who fell into more than one policy category. For instance, two new immigration bills, Bill C-55 and C-84, combined refugee policy with immigration detention policy. Both bills also linked welfare assistance policy to refugee policy through a new discourse on fraud, impacting persons who have a mental illness which will be discussed later in this section. This legislation, in context with other provincial government moves to decrease welfare and health benefits, demonstrates the rising use of neoliberal logic and the preoccupation with fraud (Pratt \& Valverde: 2002). In this system self-reliance is paramount and those requiring government services are stigmatized.

Before looking at this in greater detail, it is important to note a humanitarian development. The refugee determination system, created through Bill C-55 emerged 
following a Supreme Court decision. The Singh Decision (1985) made it mandatory for the government to provide refugee claimants the right to an oral hearing. An important component of the decision was the Supreme Court's ruling that "everyone" in section 7 of the Charter of Rights and Freedoms includes anyone physically in Canada and anyone trying to enter a Canadian port of entry. This ruling extended Charter rights to all persons in Canada regardless of their immigration status (Pratt 2005: 66).

While the Singh decision can be read as a humanitarian victory for refugee applicants, one of the big criticisms of the advent of the Charter in general was its failure to protect group rights. The Charter is more focused on the individual. There is also no mention in the Charter to social rights - the right to education, and healthcare for example. ${ }^{8}$ While non-citizens, like those in Canadian detention centres, could use the Charter to argue for equal access to healthcare to those not inside a detention facility, the likelihood of winning would be slim given that social rights are not guaranteed. In other words, the Charter was a humanitarian policy endeavor, yet it perpetuated the policy history of the Clark era of two classes of rights and entitlements to health care - Canadian citizens on one hand and persons without citizenship below them.

Bill C-55, introduced in May of 1987, launched the inland refugee determination system. It was designed to "ensure the protection of legitimate refugees, while deterring the 'shameful manipulation' of false or abusive claims". ${ }^{9}$ Pratt and Valverde argue that in the late 1980s and early 1990s Canadian governments (both provincial and federal) began to view fraud as a 'crime greater than theft' (Pratt \& Valverde 2002: 139). Bill C-55 essentially tried to make it harder for a person to make a refugee claim. They expanded the definition of persons inadmissible to make a claim, refused those who landed on safe 
third country soil before coming to Canada, disallowed claims by persons with a criminal record, and denied claimants to re-submit if their original claim was denied (Pratt 2005: 100).

Bill C-84, the Deterrents and Detention Bill, the second significant piece of legislation from 1987, introduced new measures to control Canada's borders against the smuggling of refugees. The legislative aim was to "preserve for persons in genuine need of protection access to the procedures for determining refugee claims and to respond to security concerns, including the fulfillment of Canada's obligations in respect of internationally protected persons (emphasis added)" (Bill C-84 1987: section 1).

According to the legislation, persons arriving without identity documents (often refugee claimants) would be detained. Transportation companies and smugglers caught in the act of transporting refugee claimants without authorization faced hefty fines and jail terms, and another provision permitted Canadian coastguards to turn boats away that may be carrying refugees (Kelley and Trebilcock 1998: 417).

While Bill C-55 was aimed to prevent bogus claimants from entering the refugee process in Canada, Bill C-84 aimed to shut out access to the inland determination system for all refugee claimants - including genuine refugees (Kelley and Trebilcock 1998: 418; Pratt 2005: 101). International events, beyond government control, led to a significant change in refugee movements. The end of the Cold War created new refugee flows towards Western Europe, Australia, Canada and the USA. The annual number of refugee applications from these countries/regions combined totaled 90400 in 1983 and jumped to 323050 in 1988, rising again at the end of the Cold War to reach 828645 in 1992. (Castles \& Miller 2003: 104). The source countries of refugees also changed. By the 
1980s, larger movements of refugees were coming from war torn countries in Latin American, Africa and Asia whereas previously most were coming from Europe. Castles and Miller argue that all of these receiving nations, including Canada, "shifted from a refugee system designed to welcome Cold War refugees from the East and to resettle them as permanent exiles in a new home, to a 'non-entrée regime', designed to exclude and control asylum seekers from the South " (Castles \& Miller, 2003: 107). This system would have a particular effect on refugee claimants with a mental illness, making them more likely to be detained as discussed earlier.

As previously mentioned, Bill C-84 punished genuine refugee claimants using smugglers and false identity documents, and increased the likelihood of these persons to be detained. The administrative backlog of refugee claimants and the development of a political discourse of phony refugee claimants around the world has led to the rise of "sustained programs of criminalization" such as refugee claimant detention where asking for protection is considered the "crime of arrival" (Weber \& Bowling 2004: 198). The concern about refugee fraud was the logic through which law and order programs developed. Yet these programs failed to reveal the shift in global migration movements to the public and the increased need for refugee resettlement.

Neither Bill C-55 nor C-84 contain provisions for persons with a mental illness they are given no 'vulnerable group' status and are subject to the same detention rules and refugee claim hearing procedures as other immigrants and refugees.

Much in the same way that new immigration legislation punished all refugees, new legislation changing the social entitlements of Canadians punished all those on social assistance regardless of their level of need. In the domain of health and welfare, 
provincial cutbacks in the 1990s affected the mental health of Toronto resident immigrants and refugees as well as those living with a mental illness.

In 1995 , the provincial government of Ontario put in place a $21.6 \%$ reduction in welfare payments. In 1996, the federal government reduced the Canada Health and Social Transfer by $23 \%$ in the areas of health, welfare, social services and post-secondary education. These had a direct impact on the provision of health services to immigrants and refugees (Steele et al. 2002: 121). Pratt \& Valverde argue that a fundamental shift in social values occurred during this period regarding persons in need of social assistance including those with a mental illness,

Many have now come to regard welfare recipients, now under constant suspicion of 'cheating', as offending our sense of fairness, our valorization of merit and individual accountability. Cheaters and by extension all those whose workless life is read as a lazy lifestyle choice, are seen as a serious threat to 'the system' (Pratt \& Valverde 2002:140).

The $21.6 \%$ reduction in provincial social assistance plans directly affected immigrants and refugees who experienced an increase in poverty levels and more stress as a result of navigating the increasingly restrictive social assistance system. More stress and less support have resulted in higher degrees of mood disorders and increases in suicidal behavior among Toronto's immigrants and refugee population (Steele et. al.: 2002: 121).

Cutbacks were also aimed at newcomers seeking mental health services. The Interim Federal Health Program, created in 1995 and discussed earlier, allowed for one psychiatry visit. In a study, one participant working in the mental health sector argued "If you have someone who is very sick with depression or post-traumatic stress disorder because they have been tortured or incarcerated, it is often quite hard to get repeat consultations and ongoing care" (Steele et al. 2002: 121). The result is that persons on 
IFH who are unable to get mental health services covered, turn to provincially funded community health services for treatment. Persons in detention, also covered under IFH, do not have this option. As such, a person with a mental illness who is in detention has an even smaller chance of accessing mental health supports.

These policy changes - Bill C-55, C-84, make sense given the governments' interests and changes in international migration. With Bill C-55 and C-84, the government was attempting to regain control over the selection of refugees - a control it used to have prior to the development of the inland refugee system (Adelman 1991: 193). If the government controls which refugees are recruited from abroad, it can select those better suited to the needs of the Canadian job market, not to mention persons whose health conditions can be cared for once here in Canada.

The reduction in spending on social assistance related to immigrants and refugees who have mental health problems was justified given some academic research on the health of new arrivals. The 'healthy immigrant effect', a phenomenon which is disputed yet widely used by government policy makers argues that, on average, immigrants arriving in Canada have a higher level of health than their equivalent (in age and gender) Canadian born counterpart. Over time, a persons' health status is said to decrease slightly to match Canadian born persons. ${ }^{10}$. Policymakers essentially had academic proof that immigrants are healthy when they arrive and used this to conclude that mental health programming did not need to target immigrants and refugees. The development of the IFH, and its lack of adequate mental health care coverage, is proof of the legitimacy accorded the "health immigrant effect" literature. 
The policy history from Clark's era of the undeserving immigrant, the neoliberal preoccupation with criminalizing the needy and now medical research stating that migrants should be self-sufficient upon arrival all worked together to create a discourse that is hostile to the idea of government obligations to assist immigrants and refugees with mental health services.

It is important to note the legitimacy the government has received over the years to introduce legislation that in effect marginalize refugees, immigrants and immigrants with a mental illness. According to opinion poll data, public perceptions of immigrants and refugees have hardened since the 1990s. A 1994 Angus Reid poll revealed that almost $50 \%$ of Canadians thought the government was admitting too many immigrants and approximately one third thought that immigrants took jobs away from Canadians, overused the health care system and were responsible for an increase in crimes. ${ }^{11}$ IpsosReid found in 1999 that $60 \%$ of Canadians supported the belief that Canada should make its legislative priority to "stop illegal immigrants, rather than encourage qualified immigrants to come to Canada". ${ }^{12}$ The final segment of this section examines the most current legislation related to immigrant health and the continuing law and order framework used to govern immigration.

\section{The Immigration and Refugee Protection Act (2002) and September 11th}

Just preceding the events of September $11^{\text {th }}$, the government tabled a new immigration act, the Immigration and Refugee Protection Act (IRPA). The bill became a law in 2002. The overarching theme of this Act, emphasizes exclusion in relation to national security and its connection to international organized crime and fraud. Detention 
measures, particularly ones referring to detention on the grounds of identity (from Bill C84) are even more pronounced. Immigration officers can arrest without a warrant and have the power to detain non-nationals for the purposes of completing an investigation (Pratt 2005: 51).

While it is the first immigration act to include "refugee protection" in the title, no new protections were formally introduced. The most significant method of protecting refugees, an appeal body enabling a claimant to challenge a negative refugee board decision, was not included in IRPA. Also assumed is that legislation and more specific guidelines on the enforcement side of immigration will protect the "genuine" refugee claimant (Pratt 2005: 5).

The public concern about immigrants being either a 'drain on healthcare' or 'criminals' was addressed in provisions of inadmissibility for health grounds. While Canada has a long history of excluding people from entering Canada for health grounds, there is new language in IRPA reflecting the transition to neoliberal governance. ${ }^{13}$ According to section 38 of IRPA, "A foreign national is inadmissible on health grounds if their health condition (a) is likely to be a danger to public health; (b) is likely to be a danger to public safety; or (c) might reasonably be expected to cause excessive demand on health or social services" (IRPA 2002).

Part (b) is a new component of the legislation: the other two conditions have been part of immigration legislation of the past. Who did legislators have in mind when drafting this condition? It is possible that someone who has a communicable illness that may try to intentionally harm persons in Canada and hence be more a threat to public safety than simply a threat to public health. An example that comes to mind is someone 
who is HIV positive with a history of sexual assault convictions who attempts to enter Canada. This type of situation is highly unlikely. An argument can be made that persons with a mental health issue were one of the groups legislators thought of when drafting part (b), specifically those who an immigration officer may view as dangerous and likely to threaten public safety. I would argue that this provision is a direct result of neoliberal governance initiatives that reframe persons with a mental illness as a threat, particularly when combining this legislation with the detention guidelines mentioned earlier which link mentally unstable behaviour with a threat to public safety. If this is the case, IRPA is perpetuating stereotypes of the mentally ill and contributing to the lack of policy attention paid to persons with a mental illness in Canada.

The provision also renders the mentally ill even more vulnerable to detention at the border when trying to enter Canada, particularly given IRPA's enhanced detention powers for the purpose of completing an examination.

The only mention of health policy in IRPA is this reference to inadmissibility the decision to let someone in or not. Some in the health field have argued that immigration legislation ought to address the health conditions of immigrants and refugees once they are in Canada and the impact these may have on the healthcare system (Gushulak \& Williams 2004: I-28). IRPA reflects the longstanding tradition of ignoring the issue of healthcare rights for immigrants and refugees.

What can be gathered then, is that concerns about public safety and national security, particularly in the domain of immigrant health and detention, were part of the policy reality prior to the events of September $11^{\text {th }}$ (Pratt 2005: 3). 
The September $11^{\text {th }}$ terrorist attacks did influence the number of persons in immigration detention. In 1996-7 - 6,400 people were held in immigration detention. In $2000-1-8,786$ were detained. The year of the attacks, 2001-2002, the number rose to 9,542. In the year 2002-2003, the numbers went up again to 11,503 (Pratt 2005: 43). This is particularly troublesome in the context of persons with a mental health issue, who thanks to the legislation, were more at risk of being detained. The next section will look at the use of law and order to define persons with a mental illness, particularly the 'risks' they pose to Canadian society.

\section{Governing Through Crime and Risk Management}

\section{Thinking Through Neo-Liberal Governance}

The previous section explored various modes and means through which neoliberal governance appeared in the areas of mental health and immigration paying particular attention to policy outcomes. This section takes an even closer look, and demonstrates how neo-liberal governance created room for a crime-oriented perspective on social welfare policy - known as governing through crime. The governing through crime framework could not have come about without the support of political elites and, to a lesser extent, the media. Their role will also be explored in the context of how perceptions of persons with a mental illness and refugees, as separate categories, reinforced stigma and made persons who possess both labels particularly vulnerable. 


\section{Governing Through Crime}

Crime as a policy area has dominated the politics of Western nations including Canada and the US from the 1960s onwards. It has moved beyond governing street and petty crime to determine how social services are perceived and run, how schools fight the 'war on drugs', and how both the middle class and marginalized groups are 'managed'. This is known as 'governing through crime' - where political elites use the language of crime and punishment techniques to govern other areas of social life (Simon: 1997; Simon 2007).

In recent years, the 'governing through crime' framework has been connected to Canadian immigration discourse. It is argued that an emphasis on fighting immigration crimes has shaped major immigration legislative changes since the 1990s (Pratt and Valverde: 2002). A new discourse emerged focusing on the negative aspects of the refugee determination system namely the advent of false refugee claims (phony refugees), the costs associated with refugee processing, and the ineffective rate of deportation of failed refugee claimants. This coincided with a discussion on the 'waste' and fraud plaguing Canada's social assistance programs. An intersection of both fields welfare and immigration policy - resulted in crime-oriented policies aimed at eliminating refugee fraud and more restrictive social assistance benefits to curb welfare abuse. Refugees requiring social assistance bore the brunt of the new 'get tough' policies. For example, a study of Somali refugees in Ontario conducted by Pratt and Valverde reveals how persons of colour, those on welfare, and those who are refugees became more socially and politically demonized and isolated as a result (Pratt \& Valverde 2002: 154). 
The immigration-welfare combination studied by Pratt \& Valverde is an example of two policies areas which, up until then, had been perceived in isolation from each other. The authors argue that research needs to account for the new type of social realities that emerge for people who are impacted as a result of being implicated in both policy regimes - people that are both refugees and on social assistance (Pratt \& Valverde 2002: 159). This hybridity is a result of both neo-liberal governance emphasizing refugee and welfare fraud and a governing through crime response - the toughening of welfare and refugee legislation. The result is to render persons from multiple marginal groups, to become further isolated.

I argue that the same situation presents itself for persons with a mental health issue who also happen to have immigration problems. Neo-liberal governance - in this case the rise in risk management assessments - are pushing persons who fall into two separate policy categories - immigration and mental health - to the social margins.

\section{The Mentally Ill, Immigration Detainees and Risk Management}

Risk management became a major feature from the 1970s onwards in the United States, Australia, New Zealand and Canada and coincides with the collapse of the old penal system and the rise of neo-liberal corrections management (Rose 2002: 223). Previously, institutionalized mentally ill persons were evaluated by psychologists for their potential 'dangerousness' to the public, decisions that affected whether or not they could be released. This evaluation tool was used in Britain, the United States, Canada and Australia. In the mid 1970s, American human rights activists challenged the accuracy of psychiatric evaluations. Through a series of court cases, it was revealed that psychiatrists' 
assessments were not very accurate and that some mentally ill patients and prisoners were being unnecessarily detained (Rose 2002: 211).

These same advocates pushed for a more scientific basis for analyzing detained mentally ill persons. Risk management was developed as a response. The aim of risk management is to anticipate future actions, particularly any violent episodes, by calculating the likelihood of such events happening. There was not a simple shift from one term to the other; instead, risk management became one way in which the criminal justice system infiltrated institutions previously deemed strictly for welfare. In the past, an evaluation of danger was done by a psychiatrist and applied to only a subset of the mentally ill. Now, hospital and prison workers were called upon to evaluate each patient or detainee and classify each one as either low, medium or high risk. (Rose 2002: 211).

In the public health/mental health policy context, risk assessment takes away from a focus on the diagnosis and requires psychiatric professionals to focus on protecting the community at large. The result is fewer measures in place to protect persons with a mental illness from "actual or symbolic violence faced at the hands of the community" (Rose 2002: 217).

Risk management and its corresponding lack of protections for the mentally ill has also informed immigration detention pratices. All detainees are now considered to carry some degree of risk - the government outsources detainee management to private security firms and part of that job involves participating in risk assessments. These assessments determine whether an immigration detainee gets placed in a provincial jail or an immigration detention facility. Jails are facilities for 'high risk' immigration detainees whereas immigration facilities are for 'low risk' persons (Standing Committee on 
Citizenship and Immigration Evidence Session April 22, 1998). Immigration detainees with criminal charges are often classified as 'high risk' and placed in provincial prisons. Yet security personnel and immigration employees often threaten to re-classify and transfer 'difficult' 'low risk' detainees to provincial prisons housing 'high risk' immigration cases. This includes the mentally ill and persons at risk of suicide.

Several sources have confirmed that, in practice, persons with a mental illness are routinely transferred to the provincial prisons regardless of having no criminal record in Canada (Pratt 2005: 41; UN Report of the Working Group on Arbitrary Detention Visit to Canada 2005: 20). The transfer of persons with a mental illness to jails, through the use of risk assessments, is an aspect of neo-liberal governance that is failing to consider the human rights of mentally ill detainees for two reasons: detainees are not necessarily getting better mental health care in the prison system and they can face longer periods in detention as a result of their illness, not to mention that they have not committed a crime. Psychologists and mental health professionals apparently spend more time doing risk management intakes to satisfy corrections guidelines and less time dealing with prisoners' problems, according to a follow up report to a Senate report on mental illness and addiction in Canada. Bernard Galarneau, a mental health professional in the corrections system reports, "With a caseload of anywhere from 100 to 200 inmates there is little time for genuine psychotherapy. You mostly work as a firefighter. You extinguish fires, crises as they arise, and you do a lot of risk assessments" (Senate Report Out of the Shadows At Last 2006: 306-7).

In the criminal corrections system, persons with a mental illness are often held for periods of time longer than those without a mental illness, even though there is no 
correlation between mental illness and a likelihood to re-offend (Poporino \& Motiuk: 1994). It is likely that immigration detainees with a mental illness, and no history of criminality, will spend more time in jail as a result of their illness. ${ }^{14}$

A study conducted for the Correctional Service of Canada shows that individuals diagnosed with a mental illness receive fewer opportunities for release and higher risk classifications than prisoners who have similar criminal histories. For example, an offender with a mental illness is less likely to obtain early release on parole and more likely to obtain a release requiring mandatory supervision. Interestingly, when both mentally ill and non-mentally ill prisoners were released, the latter were more likely to re-offend, putting into question the increased control and management of mentally ill offenders (Porporino \& Motiuk 1994: 21).

Risk management used for persons with immigration and mental health problems serves to increase detention time resulting in their ultimate exclusion and social isolation. In the last thirty years, political elites have conveyed the image of refugee claimants and the mentally ill as dangerous, deserving of social exclusion, through the use of media outlets (Creese: 1992). While there are persons working in government who oppose this negative portrayal of refugees and the mentally ill, it appears that their positions and policy suggestions do not often make the cut once legislation is passed. The public hears and reads the dominant stereotypes lending legitimacy to increasing penal oriented policies. This next section will examine the role of political elites in power and the mass media in conveying the need for more punitive measures to control the mentally ill. 


\section{Role of Elites/Mass Media}

Given their ready access to public venues and the mass media, political elites attempt to mold and alter public opinion with their views of state and society. Journalists often depend on them to obtain information and this relationship of "mutual interdependence" enables government officials to shape and define the problems of the day (Beckett: 1997: 6). In the US, when the economy took a downturn in the late 1970s, elites presented a new version of the criminal as an individual - a rational and calculating actor - deserving of punishment. The reframing of offenders in this light coincides with increasing public support for harsher anti-crime policies including more incarceration (Beckett 1997: 6-7).

In Canada, when public confidence in the refugee determination system waned due to the administrative backlogs and increasing costs, political elites highlighted the individual refugee claimant's role in the backlog, drawing attention away from government responsibility in the matter. For example, the Legislative Review Advisory Group, when charged with examining Canadian detention law, reframed the issue of detention on identity grounds and put the blame on the refugee claimant. Detention for identity reasons is primarily designed for refugee claimants who often rely on false documents (Kelley and Trebilcock 1998: 418). The Legislative Group argued detention should be "linked to the persons' failure to meet or comply with the objective and codified requirements (emphasis added)" (Not Just Numbers Report 1998: 8). Amnesty International Canada, as previously discussed, objected to this redefinition of detention on identity grounds, arguing that the refugee claimant may be trying to be cooperative but the governments' threshold for compliance is often unfair. 
For example, a demonstration of cooperation often involves authorizing immigration agents to apply for a passport for the detainee - who if making a claim against their country of origin - could place themselves in danger (Amnesty International Canada Report 1988: 20). Amnesty's view was in the minority and the Legislative Review Advisory Group succeeded- the latest immigration legislation contains a section about justifying continued detention if a detainee fails to comply. The Immigration Enforcement Manual on Detention which is a legislative guideline used by immigration officers and board members deciding the fate of detainees, also sanctions continued detention if a refugee claimant is not seen as cooperative with $\mathrm{CIC}$ to obtain identity documents (IRPA 2001 Section 58 (d); CIC Immigration Manual ENF 20 Section 5.8). What all this shows is an increasing emphasis on individual responsibility, a shift reflective of neoliberal preoccupations regarding the governance of marginalized groups. In addition to political elites, the decisions of mass media regarding coverage of illegal activity by persons with a mental illness or without citizenship have influenced how refugee claimants and the mentally ill are perceived.

Studies on newspaper content reveal that reports of mentally ill persons committing violent crimes are featured more often and in a more eye catching way than more positive articles about persons with a mental illness (Simmie 2001: 304). This is problematic given that up to one third of Canadians get their information about the mentally ill through the media (Senate Standing Committee on Social Affairs, Science \& Technology: Mental Illness \& Addiction in Canada: Report 1: 43). The perpetuation of negative stereotypes reinforce the notion that persons with a mental illness are dangerous and create a justification for provisions such as those in the Immigration Enforcement 
Manual on Detention allowing for the continued detention of persons who are 'mentally unstable' due to their being a 'danger to the public', as their illness can point to "future violent behavior" (CIC Immigration Manual ENF 20 Detention Manual Section 5.6: 6). Negative news coverage creates more stigma for persons who have immigration problems and mental health issues.

In the late 1980s, several boat arrivals with refugee claimants off of Canada's coasts sparked a public debate due to extensive media coverage. The debate focused on whether spontaneous arrivals were legal or criminal in nature and demonstrate how political elites used media outlets to gain support for their new crime and punishment oriented immigration policy namely Bill C-84 - The Refugee Deterrents and Detention Bill (Creese: 1992).

In the summer of 1986,155 Sri Lankan Tamils were found hidden in a ship off the Newfoundland coast. All had come to claim refugee status in Canada. In August of 1987,174 Sikh refugee claimants arrived by boat. According to a newspaper content analysis of the Globe and Mail, the media and politicians fabricated a refugee crisis. According to Gillian Creese, media reports portrayed the refugee claimants as having no basis to their claims of persecution. They were revealed instead as regular migrants who had jumped the immigration queue and coming for economic reasons (Creese 1992: 129). According to Creese's findings, of 92 articles published in 1986 on refugee issues in general, covering situations abroad and in Canada, half covered the Tamil situation in the east coast. A year earlier, half as many articles had been published about refugee issues - that is an increase of $50 \%$ and coverage surrounding one lone migration event. In 1987, the Globe published 187 on refugees and the Sikh situation took up a third of that 
years' coverage. Many news reports focused on the lack of proper documents presented by both the Sikhs and Tamils upon arrival - equating this with criminal activity. Making a refugee claim, with or without proper documents is legal, yet newspaper reports often failed to mention this. The Sikh and Tamil arrivals, as covered in the news, revealed a refugee determination system gone terribly wrong, where migrants were taking advantage of kind hearted Canadians. Anti-immigrant supporters and non-refugee immigrant communities who favored a reduction in Canada's refugee intake and an increase in family class sponsorships were incensed and formed the support base through which the government could push through its new 'tough on refugee fraud' agenda (Creese: 130131).

There were many voices of opposition to both the negative portrayal of refugee claimants and the impediments set up by the legislation to curb their movement into Canada. Fernand Jourdenais, a member of the conservative government and then chair of the House of Commons Standing Committee on Labour, Employment and Immigration opposed the legislation of his party. He argued that the government was to blame for the backlog, the illegal migrants and smugglers - the overly restrictive legislation was unnecessary, he argued, given the small numbers of refugee claimants coming to Canada (House of Commons Debates, 11 August 1987, 8047).

The Ontario Criminal Lawyers' Association argued that the detention component of Bill C-84 violated sections 7, 9, and 12 of the Charter of Human Rights and Freedoms (Senate Standing Committee, 6 October 1987, 30:8). Jerry Grafstein, a Liberal senator also accused the government of manipulating popular belief on the magnitude of the refugee crisis (Debates of the Senate, 28 October 1987, 2084). In spite of these concerns, 
the provisions which affect refugee claimants (and those with a mental illness even more) were passed and have been successfully incorporated into IRPA as discussed in earlier sections. The implications of immigration policy and negative public perceptions affecting the issue of detaining mentally ill persons in immigration centres will be discussed in the final section.

\section{Conclusions}

This paper reveals a number of concerns about the treatment of migrants with mental health issues, particularly those detained for immigration reasons. A paradigm shift towards neoliberal governance, including an increasing emphasis on self-reliance within health policy combined with the primacy of individual accountability and law and order in immigration policy, is largely responsible for the present day situation. There are, of course, traces of neoliberal ideas from Canada's policy past, proving that the underpinnings of neoliberalism are not all new. The following are some conclusions based upon this analysis of research, legislation and policy.

First, it is clear that jails are not an appropriate venue for mentally ill immigration detainees. Such persons have not committed a criminal offence and should not be placed in prison. This is harsh and cruel punishment for something that is not the fault of the detainee. As noted, research shows that prisons are not an appropriate environment for any person with a mental health issue. Also, even if somehow the transfer could be justified, Correctional Service Canada and the provincial equivalent bodies need to work on the availability of proper mental health supports for prisoners because many facilities are ill-equipped and staff are unable to attend to the needs of the population (Out of the Shadows at Last: Senate Report 2006: 311-312). 
Second, this paper raises concerns about human rights. Every detainee experiences some degree of distress when detained. However there are people who require mental health treatment and medication, who may have a history of mental illness and who are therefore not like every other detainee. Under the Interim Federal Health program, which manages both detained and non-detained health coverage, minimal to no access to mental health supports exists. The provincially funded community health centres provide mental health treatment for those not detained, yet those in detention do not have this option. This is unequal treatment, it is discriminatory and violates the human rights of the mentally ill in detention. Immigration detention is supposed to be administrative, not punitive.

Third, there is the issue of accountability. Canada Border Services Agency, the agency responsible for immigration detention, produces very few reports about their service delivery in detention centres. Most researchers and members of the Senate and House of Commons must rely on anecdotes and interviews with non-governmental organizations. Few statistics are available on how many people are detained, what the operating procedures are inside the facility and how staff are trained and disciplined. Part of the problem lies in the outsourcing. While government employees work in detention facilities, private security companies handle most of the disciplinary work. Private companies cannot be held accountable in Parliament. Yet if Canadians are paying to hold persons in immigration centres, they have a right to know how they operate and what safeguards against detainee abuse they contain. We need more than simple budget reports. These types of reports do not indicate how people are being treated. 
Fourth, it is evident that the average Canadian needs to make an effort to learn more about the issues, to look beyond newspaper coverage and what politicians say. The neoliberal era has resulted in a shift of mindset, largely due to political elite guidance and media stereotyping of the groups concerned. Public opinion polls, as evidenced in this paper, emphasize increasing support for the use of a law and order framework to govern socially marginalized persons. For this to change, persons need to engage critically with their surroundings.

\section{Areas for Future Research}

Pratt \& Valverde have broadened the scope of inquiry for the study of immigration policy and immigrant settlement. It is important to pay attention to combinations of social marginalization that are created today and how they affect persons who are, for example, non-white and an immigration detainee and affected by a mental illness. Research ought to investigate other bases for discrimination that may be affecting the way migrants are experiencing Canada.

More research also needs to be devoted to health policy and its link to immigration. While health policy is often considered a provincial responsibility and nothing to do with federally run immigration policy, federal responsibility does exist in the realm of health services, particularly for anyone in a prison or immigration detention facility. The connections between departments, the lack of interdepartmental coordination and the balance of power all need to be studied in order to understand the present problems. 


\section{The Policy Future}

This is a good time to be examining this issue. Mental health policy in Canada is an issue getting political attention. In March of 2007, the Mental Health Commission of Canada was formed due to funding from the federal government. It is a national body looking into issues affecting persons with a mental illness. Two of its main initiatives are creating a national strategy for dealing with issues of mental health across Canada and the undertaking of a nation wide anti-stigma campaign. ${ }^{15}$ To get the commission to address the issues emanating from this case study, it will be imperative to connect immigrant and refugee communities experiencing mental health concerns to the national strategy project, and for advocates working with detained migrants, to make their particular concerns known. Researchers can also help by looking into the issues that arise at the intersections between mental health policy, criminal justice and immigration policy to help policymakers and corrections personnel make better choices. 


\section{ENDNOTES}

\footnotetext{
I Senate Standing Committee on Social Affairs, Science and Technology. "Out of the Shadows at Last: Transforming Mental Health, Mental Illness and Addiction Services in Canada." Ottawa: Minister of Public Works and Government Services, 2006.

${ }^{2}$ For a discussion of jobs see Peter S. Li (2003) Destination Canada; for a discussion of discrimination faced when renting or buying property see Robert Murdie (2002) "The Housing Careers of Polish and Somali Newcomers in Toronto's Rental Market".

${ }^{3}$ For a gender, class and race analysis of immigration issues see any of Sedef Arat-Koc's work; For a discussion of racism in immigration policy see Alan Simmons (1998) "Racism and Immigration Policy" in Vic Satzewich (Ed.) Racism \& Social Inequality in Canada.

${ }^{4}$ See Roberts (1988) Whence They Came: Deportation from Canada 1900-1935.

5 For studies on mental health effects of detention from Australia see also Sultan and O'Sullivan's (2001) "Psychological Disturbances in Asylum Seekers Held in Long Term Detention: A Participant-Observer Account". Medical Journal of Australia 175:593-6.

${ }^{6}$ Increasing numbers of refugee claimants arriving without documents, particularly in the mid 1980s prompted the legislation change. These events will be discussed in greater length later in the paper.

${ }^{7}$ For other cases in Australia see S. v. Secretary DIMIA or the Comrie Report regarding Vivian Alvarez.

${ }^{8}$ For a discussion of these arguments see Michael Mandel (1989) The Charter of Rights and the Legalization of Politics in Canada.

${ }^{9}$ Weiner, House of Commons Debates, 18 June 1987, 7329, quoted in Kelley and Trebilcock (1998), The Making of the Mosaic: 416.

${ }^{10}$ For a discussion of the 'healthy immigrant effect' see J Chen, E Ng, R Wikins, (1996) "The Health of Canada's Immigrants in 1994-5" Health Rep; 7 (4): 33-45; JB Newbold and J. Danforth (2003)Health Status and Canada's Immigrant Population. Soc Sci Med; 57:1981-95.

${ }^{11}$ Angus Reid Group, Multiculturalism and Canadians: Attitudes Study 1991, Ottawa: Multiculturalism and Citizenship Canada, 1991, quoted in Pratt 2005: 67.

${ }^{12}$ Ipsos-Reid Group/Globe and Mail/CTV poll on Canadian attitudes towards immigrants and immigration, 22 November 1999, quoted in Pratt 2005: 67.

${ }^{13}$ See Kelley and Trebilcock (1998) for this history.

${ }^{14}$ Immigration detainees with a mental illness are often held under the 'danger to the public' provision of IRPA and do face longer periods of detention than immigrants without a mental illness. This is due to the legislative guidelines mentioned in the first section with respect to mental instability. The additional issue with major human rights implications is that immigrants with no history of criminality but with a mental illness can face longer detention periods than persons convicted of crimes.

${ }^{15}$ Information from www.mentalhealthcommission.ca.
} 


\section{Bibliography}

\section{Legislation}

An Act to Amend the Immigration Act, 1976, and to Amend Other Acts in Consequence Thereof (the Refugee Deterrents and Detention Bill), S.C. 1988, c.35.

An Act to Amend the Immigration Act, 1976, and to Amend Other Acts in Consequence Thereof (the Refugee Reform Bill), S.C. 1988, c.36.

Immigration and Refugee Protection Act, S.C. 2001

\section{Canadian Government Publications and Other Documents}

Canadian Task Force on Mental Health Issues Affecting Immigrants and Refugees (1988). After the Door has been Opened: Mental Health Issues Affecting Immigrants and Refugees in Canada. Minister of Supply and Services Canada.

Citizenship and Immigration Canada. Immigration Manual, Chapter ENF 20, s. 5 (2), "Departmental Policy, General." October 2002. www.cic.gc.ca/English/resources/manuals/enf/index.asp

-. Legislative Review Advisory Group. Not Just Numbers: A Canadian Framework for Future Immigration. Ottawa: Minister of Public Works and Government Services, 1997.

Immigration and Refugee Board. Guideline on Procedures with Respect to Vulnerable Persons Appearing Before the IRB. http://www.irb-cisr.gc.ca/en/references/policy/guidelines/vulnerable_e.htm

Health Canada (2006). The Human Face of Mental Health and Mental Illness in Canada 2006. Minister of Public Works and Government Services.

House of Commons Debates, 11 August 1987, 8047.

House of Commons Standing Committee on Citizenship and Immigration. Transcripts of Hearings on Removal and Detention Pursuant to Standing Order 108 (2) March 1998. Ottawa, October 1997- May 1998.

Senate, Debates, 28 October 1987.

Senate Standing Committee, Debates, 6 October 1987, 30:8.

Senate Standing Committee on Social Affairs, Science and Technology. "Mental Health, Mental Illness and Addiction Report 1: Overview of Policies and Programs in Canada." Ottawa: Minister of Public Works and Government Services, 2004.

-. Evidence Session: February 23, 2005.

-. "Out of the Shadows at Last: Transforming Mental Health, Mental Illness and Addiction Services in Canada." Ottawa: Minister of Public Works and Government Services, 2006. 


\section{Articles and Books}

Adelman, Howard. "Canadian Refugee Policy in the Post-War Period." In Howard Adelman, ed., Refugee Policy: Canada and the United States, 172-223. Toronto: York Lanes Press, 1991.

Amnesty International. Response to the Report of the Legislative Advisory Group. March 1998. http://www.amnesty.ca/Refugee/news/Canadian.php

Arat-Koc. "Neo-liberalism, State Restructuring and Immigration: Changes in Canadian Policies in the 1990s." Journal of Canadian Studies 34,2 (Summer 1999): 31-56.

Beckett, Katherine (1997). Making Crime Pay: Law and Order in Contemporary American Politics. Oxford: Oxford University Press.

Beiser, Morton. "The Health of Immigrants and Refugees in Canada." Canadian Journal of Public Health 96:2 (Mar/Apr 2005): S30-S44.

Castles, Stephen \& Miller, Mark J. (2003). The Age of Migration: International Population Movements in the Modern World. Third Edition. New York: Guilford.

Clark, David. "Neoliberalism and Public Service Reform: Canada in Comparative Perspective." Canadian Journal of Political Science 35:4 (December 2002): 771-793.

Creese, Gillian. "The Politics of Refugees in Canada" in Vic Satzewich, ed., Deconstructing a Nation: Immigration, Multiculturalism \& Racism in '90s Canada. Halifax: Fernwood Publishing, 123-145, 1992.

Dowbiggin, Ian. “'Keeping This Young Country Sane': C.K. Clark, Immigration Restriction, and Canadian Psychiatry, 1890-1925". The Canadian Historical Review: 76 (4) (December 1995): 598-627.

Fellner, Jamie. “A Corrections Quandary: Mental Illness and Prison Rules". Harvard Civil Rights - Civil Liberties Law Review 41 (2006): 391-412.

Gagnon, Anita J. " Discussion Paper 40: Responsiveness of the Canadian Health Care System Towards Newcomers" Commission on the Future of Health Care in Canada (Romano Commission). Government of Canada: 2002.

Gushulak, Brian D. \& Williams, Linda S. "National Immigration Health Policy: Existing Policy, Changing Needs, and Future Directions." Canadian Journal of Public Health 95:3 (May/June 2004): I-27-I-29.

Kelley, Ninette and Trebilcock, Michael (1998). The Making of the Mosaic: A History of Canadian Immigration Policy. Toronto: UofT Press.

Knowles, Valerie (1997). Strangers at Our Gates. Canadian Immigration and Immigration Policy, 1540-1997. Toronto: Dundurn Press. 
Li, Peter (2003). Destination Canada: Immigration Debates and Issues. Oxford, Oxford University Press.

Palmer, MJ. "Inquiry into the Circumstances of the Immigration Detention of Cornelia Rau," Commonwealth of Australia, 2005.

Porporino, Frank J. and Laurence L. Motiuk. The Prison Careers of Offenders with Mental Disorders. Correctional Service Canada: Research Branch, Report R-33, 1994.

Pourgourides, Christina. "The Mental Health Implications of the Detention of Asylum Seekers." In Jane Hughes, Fabrice Liebaut, eds., Detention of Asylum Seekers in Europe: Analysis and Perspectives. Martinius Nijhoff: 1998.

Pratt, Anna \& Mariana Valverde. "From Deserving Victims to 'Masters of Confusion': Redefining Refugees in the 1990s." Canadian Journal of Sociology 27, 2 (2002): 135-61.

Pratt, Anna (2005). Securing Borders: Detention and Deportation in Canada. Vancouver: UBC Press.

Rose, Nikolas (1999). Powers of Freedom: Reframing Political Thought. Cambridge: Cambridge University Press.

-. "At Risk of Madness." In Tom Baker \& Jonathan Simon, eds. Embracing Risk: The Changing Culture of Insurance and Responsibility. Chicago: University of Chicago Press, 2002.

Seddon, Toby (2007). Punishment and Madness: Governing Prisoners with Mental Health Problems. Abingdon: GlassHouse Press.

Simmie, Scott (2001). The Last Taboo. Toronto: McClelland \& Stewart.

Simon, Jonathan. "Governing through Crime." In Lawrence M. Friedman and George Fisher, eds., The Crime Conundrum: Essays on Criminal Justice, 171-89. New York: Westview Press, 1997.

-.Governing through Crime. Oxford: Oxford University Press, 2007.

Steele, Leah S. \& Lemieux-Charles, Louise \& Clark, Jocalyn \& Glazier, Richard H. "The Impact of Policy Changes on the Health of Recent Immigrants and Refugees in the Inner City." Canadian Journal of Public Health 93: 2 (March/April 2002): 118-122.

United Nations. "Report of the Working Group on Arbitrary Detention: Visit to Canada." December 5, 2005. http:// daccessdds.un.org/doc/UNDOC/GEN/G05/165/34/PDF/G0516534.pdf? OpenElement

Weber, Leanne \& Bowling, Benjamin. "Policing Migration: A Framework for Investigating the Regulation of Global Mobility" Policing \& Society. Vol 14, No. 3, (September 2004):195-212. 